\title{
RESTORATIVE EFFECTS OF ALOE VERA GEL ON ALCOHOL INDUCED HEPATO-NEPHROCELLULAR DYSFUNCTION
}

\author{
Akinloye, D. I., Ugbaja, R. N., Dosumu, O. A. \\ Akamo, A. J., James, A. S., Adeyemo, A. B. \\ Department of Biochemistry, College of Biosciences, Federal University of Agriculture \\ Abeokuta, P. M. B. 2240 \\ Nigeria \\ akinloyedi@funaab.edu.ng
}

\section{ABSTRACT}

Excessive alcohol intake is associated with pathological conditions that are detrimental. Aloe vera is a plant that possesses antimicrobial and anti-oxidant properties. This study investigated the effects of Aloe vera gel on alcohol induced hepato-nephrocellular dysfunction in rats using the specific activities of glutathione-S-transferase (GST), alanine aminotransferase (ALT), aspartate aminotransferase (AST), alkaline phosphatase (ALP), gamma glutamyl transferase (GGT) and lactate dehydrogenase $(\mathrm{LDH})$ as well as concentration of some electrolytes as indices. Six groups of male albino rats containing 5 rats each were used in the experiments. Groups $A$ and $B$ were administered distilled water and $50 \%$ (v/v) alcohol for 21 days respectively. Groups C and D were administered $50 \%(\mathrm{v} / \mathrm{v})$ alcohol, while groups $\mathrm{E}$ and $\mathrm{F}$ were administered distilled water for the first $\mathbf{1 4}$ days, followed by co-administration (without stopping alcohol or distilled water administrations) of $125 \mathrm{mg}$ and $250 \mathrm{mg} . \mathrm{kg}^{-1}$ body weight Aloe vera gel respectively for 7 days. The administration of Aloe vera gel extract significantly modulated serum electrolytes imbalances with concomitant lowering of ALT, AST, ALP, GGT, LDH and GST rates when compared to group $B$. These results suggested the restoration of alcohol induced dysfunction by Aloe vera gel.

Key words: alcohol; Aloe vera; electrolytes; restoration effect; tissue damage; toxicity

\section{INTRODUCTION}

Alcohol consumption has a widespread social tradition among many populations worldwide because its moderate intake has been regarded beneficial to cardiovascular health $[15,33]$. However, excessive alcohol intake is also associated with a variety of pathological conditions varying from simple intoxication, to severe life-threatening states which are increasingly becoming important causes of morbidity and mortality globally $[15,17,27]$.

The liver is the site of essential biochemical reactions and has the function to detoxify xenobiotics [24]. It is also 
the primary organ for the metabolism of alcohol which makes it susceptible to alcohol related injuries [17, 32]. The site for elimination of reactive metabolites which is the kidney, may also be affected by excessive alcohol consumption and could cause impairment in its ability to regulate the volume and composition of fluid and electrolytes in the body $[7,30]$.

The developments of interest in the therapeutic potentials of medicinal plants against alcohol induced toxicity have become an increasing attractive area of research $[8$, 13]. Aloe vera (Aloe barbadensis Miller) is one of the four species among over 360 species known to have medicinal properties [5]. It is a tropical succulent plant that belongs to the liliaceous family $[18,24]$. Its common names include: Aloe vera, Barbados aloe, Mediterranean aloe, True aloe and Curacao aloe $[4,18,21]$. The leaf extract and/or the juice has been shown to possess: laxative, antimicrobial, wound healing, anti-inflammatory, anti-cancer, anti-diabetic and anti-oxidant properties [4, 18, 22, 26, 34, 35].

Many studies have shown the pharmacological evidence and the support of the traditional folklore medicinal usage of Aloe vera in the treatment of different toxicant induced tissue damages $[4,8,16,24,28]$. Most of the medicinal properties of Aloe vera leaves have been attributed to the presence of the polysaccharides found in the inner part of the parenchymatous tissue $[4,8]$. Thus, a continuous screening in the laboratory for its biochemical and pharmacological properties against liver and kidney impairment is necessary. A k i n lo y e et al. [2] have already reported the antioxidative potential of Aloe barbadensis on alcohol induced oxidative stress in rats. However, the restorative effects of Aloe vera on serum electrolyte disturbances induced by alcohol administration have not been completely explored. This study was therefore designed to investigate the restorative effect of lyophilized Aloe vera gel extract on alcohol induced hepatocellular and nephrocellular dysfunction in male albino rats.

\section{MATERIALS AND METHODS}

\section{Collection and authentication of plant materials}

The collection and authentication of plant materials were done as previously carried out by A k i n lo ye et al. [2]. Fresh Aloe vera plants were obtained from the Botanical garden of the department of Pure and Applied Botany and authenticated by a botanist (Professor D. A. A g b o o l a) in the department of Pure and Applied Botany, Federal University of Agriculture, Abeokuta, Nigeria. The plant was identified and authenticated with herbarium number FUNAABH0028.

\section{Extraction of Aloe vera gel}

The Aloe vera plants were washed thoroughly with clean water, rinsed with distilled water and the inner part (the gel) of the leaves was removed into a clean container and blended (homogenized) using ROSPEC $7.4 \mathrm{~V} 2000 \mathrm{rpm}$ electric blender. The homogenized gel was stored in a frozen state $\left(\right.$ at $\left.-10^{\circ} \mathrm{C}\right)$ and lyophilized at Covenant University, Ota, Ogun State, Nigeria using LTE Scientific Lyotrap ultra freeze dryer with ice capacity of $10 \mathrm{~kg}$ ( $6 \mathrm{~kg}$ in 24 hours) and temperature $-55^{\circ} \mathrm{C}$ (heat extraction rate of $-40{ }^{\circ} \mathrm{C}$ ).

\section{Experimental animals}

The approval of the Departmental Animal Ethical Committee (FUNAAB-BCH) was obtained prior to the experiment with ethical no FUNAAB-BCH-DI 017. All of the protocols and the experiments were conducted in strict compliance according to the guidelines approved by the committee. Forty-five (45) male albino rats weighing between $180 \mathrm{~g}$ and $250 \mathrm{~g}$ were purchased from the Department of Veterinary Medicine, Federal University of Agriculture, Abeokuta, Nigeria. The animals were acclimatized for two weeks before the commencement of the experiments. They were housed in plastic cages with good ventilation and were supplied with standard pellet and clean water ad libitum.

\section{Experimental design}

The experimental design was carried out as described by A k in lo ye et al. [2]. Forty-five (45) male albino rats weighing $180-250 \mathrm{~g}$ were first divided into two (2) groups of 15 animals and 30 animals. The 15 animals were given orally, $4 \mathrm{mg} \cdot \mathrm{kg}^{-1}$ body weight of distilled water for the first two weeks (14 days) of the experiments, while the other 30 animals were orally administered $4 \mathrm{ml} . \mathrm{kg}^{-1}$ body weight of $50 \%(\mathrm{v} / \mathrm{v})$ ethanol for the first two weeks (14 days) of the experiments. After the first two weeks (14 days), the 15 animals were further divided into three (3) groups (A, $\mathrm{E}$ and $\mathrm{F}$ ) of 5 animals each; group $\mathrm{A}$ served as the positive control and were further administered $4 \mathrm{ml} . \mathrm{kg}^{-1}$ body weight of distilled water for another one week (7 days); 
Table 1. Experimental Design

\begin{tabular}{lc}
\multicolumn{1}{c}{ Dosage administered } & Groups \\
\hline Distilled water for 21 days & $\mathrm{A}$ \\
$50 \%$ Alcohol for 21 days & $\mathrm{B}$ \\
$50 \%$ Alcohol (14 days) followed by & $\mathrm{C}\left(125 \mathrm{mg} \cdot \mathrm{kg}^{-1}\right)$ \\
alcohol + Aloe vera (7 days) & $\mathrm{D}\left(250 \mathrm{mg} \cdot \mathrm{kg}^{-1}\right)$ \\
$\begin{array}{l}\text { Distilled water (14 days) followed by } \\
\text { alcohol + Aloe vera (7 days) }\end{array}$ & $\mathrm{E}\left(125 \mathrm{mg} \cdot \mathrm{kg}^{-1}\right)$ \\
\hline
\end{tabular}

while groups E and F were given $125 \mathrm{mg}$ and $250 \mathrm{mg} \cdot \mathrm{kg}^{-1}$ body weight Aloe vera gel respectively for another one week (7 days) of the experiments. Twenty-four (24) animals were selected from the 30 alcohol treated group after the first two weeks (14 days) of alcohol administration. From these, 10 animals were further administered the same quantity and concentration of alcohol for the next one week (7 days) and served as the negative control group (B). The remaining 14 animals were also divided into 2 groups ( $C$ and $D)$ of 7 animals each; which were then treated with $125 \mathrm{mg}$ and $250 \mathrm{mg} \cdot \mathrm{kg}^{-1}$ body weight Aloe vera gel extract respectively after 30 minutes of alcohol administration for another one week ( 7 days) of the experiment. On the 21 st day of the experiment, after the last treatment, the animals were fasted for 12 hours overnight and were sacrificed after anaesthetized slightly. Blood samples were then collected via the abdominal vein into clean plain tubes, allowed to stand and clot for 15 minutes and then centrifuged at $3000 \mathrm{rpm}$ for 10 minutes to collect serum using the refrigerated centrifuge (BK-THRI16, Biobase Biodustry Shagdong). Kidney and stomach were excised for biochemical examination, using $10 \%$ homogenate preparation.

\section{Biochemical assays}

Glutathione-S-transferase (GST, EC: 2.5.1.18) specific activity was determined according to the method described by $\mathrm{Hab}$ ig et al. [14]. The specific activities of alanine aminotransferase (ALT, EC: 2.6.1.2), aspartate aminotransferase (AST, EC: 2.6.1.1), alkaline phosphatase (ALP, EC: 3.1.3.1), gamma glutamyl transferase (GGT, EC: 2.3.2.21) and lactate dehydrogenase (LDH, EC: 1.1.1.27) as well as the concentration of the: total protein, creatinine, uric acid, bilirubin, urea, albumin, sodium, magnesium, calcium, potassium and chloride were determined using the Randox standard kit methods of Randox Laboratory Limited (United Kingdom).

\section{Statistical analysis}

The results were expressed as the mean \pm SEM $(n=5)$. The level of homogeneity among the groups was assessed using one-way analysis of variance (ANOVA). Where homogeneity occurred, Duncans' test was used to differentiate between the groups. All analyses were done using the Statistical Package for Social Sciences (SPSS 20.0) and $\mathrm{P}<0.05$ was considered the statistically significant.

\section{RESULTS}

Table 2 shows the effects of the Aloe vera gel extract on the serum tissue damaged enzymatic markers of alcohol in the intoxicated male albino rats. The administration of alcohol significantly $(\mathrm{P}<0.05)$ elevated the serum specific activities of: ALT, AST, ALP, GGT, LDH and GST, when compared to the controls. However, co-treatment with $125 \mathrm{mg}$ and $250 \mathrm{mg} \cdot \mathrm{kg}^{-1}$ body weight Aloe vera gel extract (groups C and D) significantly lowered the elevated specific activities of ALT (with the exception of group D that showed a slight reduction), AST, ALP, GGT, LDH and GST, as compared to the alcohol treated group (group B). The administration of $250 \mathrm{mg}$. $\mathrm{kg}^{-1}$ body weight Aloe vera gel extract only, showed no significant difference in the specific activities of ALT, LDH and GGT, as compared to the control group (A).

Alcohol significantly $(\mathrm{P}<0.05)$ increased the activities of renal AST, GST and LDH in the alcohol treated groups when compared to the control group as shown in Table 3. Also, significant reductions were observed in the specific activities of renal ALT and ALP of the alcohol treated group when compared to the control group. Treatment with $125 \mathrm{mg}$ and $250 \mathrm{mg} \cdot \mathrm{kg}^{-1}$ body weight Aloe vera gel significantly reduced the elevated activities of AST and LDH with a concomitant increase in the specific activities of ALT and ALP kidney of the Aloe vera treated group when compared to the alcohol treated group (B). However, there was no significant difference in GST specific activity of group C (group administered $125 \mathrm{mg} . \mathrm{kg}^{-1}$ body weight Aloe vera gel extract) when compared to group B.

The administration of alcohol resulted in a marked increase in the stomach specific activities of GGT, ALP, GST and LDH when compared to the control group (Table 4). But, after co-treatment with Aloe vera gel extract (groups C and D), the elevated specific activities of GGT, ALP, GST 
Table 2. Effects of Aloe vera gel extract on tissue damaged enzyme markers in the serum of alcohol intoxicated male albino rats

\begin{tabular}{|c|c|c|c|c|c|c|}
\hline \multirow{2}{*}{ Parameter } & \multicolumn{6}{|c|}{ Serum (U.mg ${ }^{-1}$ protein) } \\
\hline & ALT & AST & ALP & LDH & GGT & GST \\
\hline Control (A) & $4.46 \pm 0.05^{b}$ & $5.16 \pm 0.18^{b}$ & $0.61 \pm 0.01^{a}$ & $0.96 \pm 0.01^{\mathrm{a}}$ & $0.79 \pm 0.01^{a}$ & $0.49 \pm 0.08^{b}$ \\
\hline$A L C(B)$ & $5.37 \pm 0.26^{c}$ & $6.92 \pm 0.38^{c}$ & $16.92 \pm 0.05^{\mathrm{e}}$ & $7.20 \pm 0.03^{c}$ & $9.14 \pm 0.02^{c}$ & $0.79 \pm 0.01^{c}$ \\
\hline$A L C+125 \mathrm{mg} \mathrm{A.V}(\mathrm{C})$ & $2.41 \pm 0.08^{\mathrm{a}}$ & $5.37 \pm 0.31^{b}$ & $13.86 \pm 0.35^{d}$ & $3.00 \pm 0.03^{b}$ & $3.71 \pm 0.03^{b}$ & $0.35 \pm 0.03^{b}$ \\
\hline$A L C+250 \mathrm{mg} \mathrm{A.V} \mathrm{(D)}$ & $3.46 \pm 0.13^{b c}$ & $4.81 \pm 0.09^{b}$ & $7.26 \pm 0.58^{c}$ & $1.44 \pm 0.09^{s}$ & $0.64 \pm 0.14^{s}$ & $0.44 \pm 0.07^{b}$ \\
\hline 125 mg A.V (E) & $1.69 \pm 0.10^{a}$ & $1.97 \pm 0.13^{\mathrm{a}}$ & $0.45 \pm 0.01^{\mathrm{a}}$ & $0.72 \pm 0.22^{\mathrm{a}}$ & $0.66 \pm 0.01^{\mathrm{a}}$ & $0.42 \pm 0.01^{b}$ \\
\hline $250 \mathrm{mg} \mathrm{A.V}$ (F) & $2.5 \pm 0.37^{b}$ & $2.55 \pm 0.01^{\mathrm{a}}$ & $1.51 \pm 0.03^{b}$ & $1.10 \pm 0.08^{\mathrm{a}}$ & $0.34 \pm 0.04^{\mathrm{a}}$ & $0.18 \pm 0.00^{\mathrm{a}}$ \\
\hline
\end{tabular}

These data are expressed as the mean $\pm \operatorname{SEM}(n=5)$; Values with different superscript letters along the column for each parameter

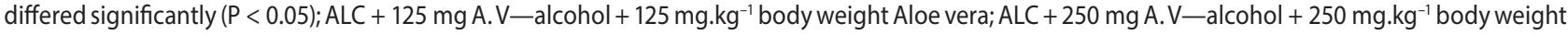

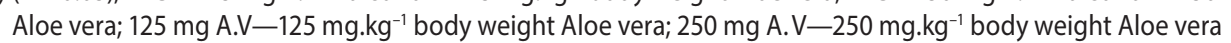

Table 3. Effects of Aloe vera gel extract on tissue damaged enzyme markers in the kidney of alcohol intoxicated male albino rats

\begin{tabular}{|c|c|c|c|c|c|c|}
\hline \multirow{2}{*}{ Parameter } & \multicolumn{6}{|c|}{ Kidney (U.mg ${ }^{-1}$ protein) } \\
\hline & ALT & AST & ALP & LDH & GGT & GST \\
\hline Control (A) & $5.97 \pm 0.15^{b}$ & $4.35 \pm 0.19^{a}$ & $4.36 \pm 0.41^{b}$ & $3.68 \pm 1.15^{a}$ & $2.40 \pm 0.22^{\mathrm{ab}}$ & $0.17 \pm 0.00^{\mathrm{a}}$ \\
\hline ALC (B) & $2.42 \pm 0.06^{a}$ & $18.75 \pm 0.35^{\mathrm{a}}$ & $1.30 \pm 0.12^{\mathrm{a}}$ & $28.04 \pm 1.84^{\mathrm{d}}$ & $2.21 \pm 0.02^{\mathrm{b}}$ & $0.58 \pm 0.00^{\mathrm{b}}$ \\
\hline ALC. + 125 mg A.V (C) & $6.06 \pm 0.44^{\mathrm{b}}$ & $13.19 \pm 0.27^{b c}$ & $1.41 \pm 0.09^{\mathrm{a}}$ & $15.32 \pm 0.95^{\mathrm{bc}}$ & $2.75 \pm 0.08^{c}$ & $0.17 \pm 0.02^{\mathrm{a}}$ \\
\hline ALC. + $250 \mathrm{mg} \mathrm{A.V} \mathrm{(D)}$ & $6.80 \pm 0.44^{b c}$ & $12.68 \pm 0.65^{b}$ & $2.09 \pm 0.32^{\mathrm{a}}$ & $11.06 \pm 2.94^{\mathrm{ab}}$ & $2.50 \pm 0.14^{a b}$ & $0.56 \pm 0.03^{b}$ \\
\hline 125 mg A.V (E) & $7.61 \pm 0.59^{c d}$ & $14.18 \pm 0.49^{c}$ & $2.82 \pm 0.21^{\mathrm{ab}}$ & $23.45 \pm 0.80^{\mathrm{cd}}$ & $1.23 \pm 0.04^{\mathrm{a}}$ & $0.23 \pm 0.01^{a}$ \\
\hline $250 \mathrm{mg} \mathrm{A.V} \mathrm{(F)}$ & $8.11 \pm 0.28^{d}$ & $16.38 \pm 0.28^{d}$ & $3.41 \pm 1.54^{c}$ & $24.12 \pm 5.66^{d}$ & $1.53 \pm 0.15^{\mathrm{a}}$ & $0.37 \pm 0.03^{a}$ \\
\hline
\end{tabular}

These data are expressed as the mean \pm SEM $(n=5)$. Values with different superscript letters along the column for each parameter differed significantly at $\mathrm{P}<0.05 ; \mathrm{ALC}+125 \mathrm{mg} \mathrm{A} . \mathrm{V}$-alcohol $+125 \mathrm{mg} \cdot \mathrm{kg}^{-1}$ body weight Aloe vera; ALC $+250 \mathrm{mg} \mathrm{A}$. V-alcohol $+250 \mathrm{mg} \cdot \mathrm{kg}^{-1}$ body weight

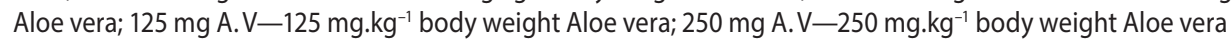

Table 4. Effects of Aloe vera gel extract on the specific activities of GGT, ALP, GST and LDH in the stomach of alcohol intoxicated rats

\begin{tabular}{|c|c|c|c|c|}
\hline \multirow{2}{*}{ Parameter } & \multicolumn{4}{|c|}{ Stomach (U. $\mathrm{mg}^{-1}$ protein) } \\
\hline & GGT & ALP & GST & LDH \\
\hline Control (A) & $6.93 \pm 0.67^{d}$ & $80.82 \pm 0.65^{\mathrm{e}}$ & $1.50 \pm 0.12^{\mathrm{a}}$ & $9.11 \pm 0.43^{d}$ \\
\hline ALC (B) & $9.06 \pm 0.32^{\mathrm{e}}$ & $176.74 \pm 0.01^{f}$ & $2.90 \pm 0.49^{b}$ & $12.96 \pm 0.01^{\mathrm{e}}$ \\
\hline$A L C+125 \mathrm{mg} \mathrm{A} . \mathrm{V}(\mathrm{C})$ & $7.74 \pm 0.73^{d}$ & $52.93 \pm 0.74^{c}$ & $1.60 \pm 0.01^{\mathrm{a}}$ & $2.13 \pm 0.02^{\mathrm{a}}$ \\
\hline$A L C+250 \mathrm{mg} \mathrm{A.V}(D)$ & $4.09 \pm 0.21^{c}$ & $55.65 \pm 0.22^{\mathrm{d}}$ & $1.21 \pm 0.06^{\mathrm{a}}$ & $2.59 \pm 0.01^{b}$ \\
\hline $125 \mathrm{mg} \mathrm{A.V} \mathrm{(E)}$ & $1.58 \pm 0.55^{\mathrm{a}}$ & $22.55 \pm 0.68^{\mathrm{a}}$ & $1.44 \pm 0.14^{\mathrm{a}}$ & $3.37 \pm 0.20^{c}$ \\
\hline $250 \mathrm{mg}$ A.V (F) & $2.49 \pm 0.2^{b}$ & $40.79 \pm 1.22^{b}$ & $1.13 \pm 0.07^{\mathrm{a}}$ & $3.68 \pm 0.02^{c}$ \\
\hline
\end{tabular}

These data are expressed as the mean $\pm \operatorname{SEM}(n=5)$. Values with different superscript letters along the column for each parameter are significantly different at $\mathrm{P}<0.05 ; \mathrm{ALC}+125 \mathrm{mg} \mathrm{A} . \mathrm{V}$-alcohol $+125 \mathrm{mg} \cdot \mathrm{kg}^{-1}$ body weight Aloe vera; ALC $+250 \mathrm{mg} \mathrm{A} \cdot \mathrm{V}$-alcohol $+250 \mathrm{mg} \cdot \mathrm{kg}^{-1}$ body weight Aloe vera; $125 \mathrm{mg} \mathrm{A.V}-125 \mathrm{mg} \cdot \mathrm{kg}^{-1}$ body weight Aloe vera; $250 \mathrm{mg} \mathrm{A.V}-250 \mathrm{mg} \cdot \mathrm{kg}^{-1}$ body weight Aloe vera 
Table 5. Effects of Aloe vera gel extract on serum - tissue damaged markers in the serum of alcohol intoxicated male albino rats

\begin{tabular}{|c|c|c|c|c|c|}
\hline Parameter & $\begin{array}{l}\text { Bilirubin } \\
{\left[\mu \mathrm{mol} . \mathrm{I}^{-1}\right]}\end{array}$ & $\begin{array}{c}\text { Urea } \\
{\left[\mu \mathrm{mol} . \mathrm{I}^{-1}\right]}\end{array}$ & $\begin{array}{l}\text { Uric acid } \\
{\left[\mu \mathrm{mol} . .^{-1}\right]}\end{array}$ & $\begin{array}{l}\text { Albumin } \\
{\left[\mu \mathrm{mol} . \mathrm{I}^{-1}\right]}\end{array}$ & $\begin{array}{l}\text { Creatinine } \\
{\left[\text { mmol. } .^{-1}\right]}\end{array}$ \\
\hline Control (A) & $11.17 \pm 1.12^{c}$ & $1.15 \pm 0.10^{b}$ & $0.11 \pm 0.01^{b}$ & $2.29 \pm 0.11^{\mathrm{b}}$ & $99.46 \pm 3.21^{\mathrm{b}}$ \\
\hline ALC (B) & $15.54 \pm 1.23^{d}$ & $2.58 \pm 0.13^{c}$ & $0.15 \pm 0.02^{c}$ & $1.62 \pm 0.10^{\mathrm{a}}$ & $108.2 \pm 4.02^{c}$ \\
\hline$A L C+125 \mathrm{mg} \mathrm{A} . V(C)$ & $13.88 \pm 1.10^{\mathrm{bc}}$ & $1.32 \pm 0.11^{\mathrm{ab}}$ & $0.12 \pm 0.01^{b}$ & $1.70 \pm 0.10^{\mathrm{a}}$ & $85.74 \pm 2.10^{\mathrm{a}}$ \\
\hline$A L C+250 \mathrm{mg} \mathrm{A.V} \mathrm{(D)}$ & $4.40 \pm 0.23^{\mathrm{a}}$ & $0.96 \pm 0.01^{\mathrm{a}}$ & $0.04 \pm 0.01^{\mathrm{a}}$ & $2.53 \pm 0.13^{b}$ & $86.95 \pm 2.40^{\mathrm{s}}$ \\
\hline $125 \mathrm{mg} A . V(E)$ & $5.18 \pm 0.43^{\mathrm{a}}$ & $1.17 \pm 0.10^{b}$ & $0.08 \pm 0.01^{\mathrm{a}}$ & $3.33 \pm 0.25^{c}$ & $101.4 \pm 5.40^{\mathrm{b}}$ \\
\hline $250 \mathrm{mg} \mathrm{A.V} \mathrm{(F)}$ & $8.78 \pm 0.55^{\mathrm{b}}$ & $1.46 \pm 0.14^{\mathrm{ab}}$ & $0.10 \pm 0.01^{b}$ & $3.79 \pm 0.32^{c}$ & $100.2 \pm 6.10^{b}$ \\
\hline
\end{tabular}

These data are expressed as the mean \pm SEM $(n=5)$. Values with different superscript letters along the column for each parameter differ significantly at $\mathrm{P}<0.05 ; \mathrm{ALC}+125 \mathrm{mg} \mathrm{A} \cdot \mathrm{V}$-alcohol $+125 \mathrm{mg}^{\mathrm{kg}} \mathrm{kg}^{-1}$ body weight Aloe vera; ALC $+250 \mathrm{mg} \mathrm{A}$. V-alcohol $+250 \mathrm{mg} \cdot \mathrm{kg}^{-1}$ body weight Aloe vera; $125 \mathrm{mg} \mathrm{A.V}-125 \mathrm{mg} \cdot \mathrm{kg}^{-1}$ body weight Aloe vera; $250 \mathrm{mg} \mathrm{A.V}-250 \mathrm{mg}^{\mathrm{kg}} \mathrm{g}^{-1}$ body weight Aloe vera

Table 6. Effects of Aloe vera gel on serum electrolytes levels of alcohol intoxicated male albino rats

\begin{tabular}{|c|c|c|c|c|c|}
\hline \multirow{2}{*}{ Parameter } & \multicolumn{5}{|c|}{ Serum electrolytes [mmol. $\left.\mathrm{I}^{-1}\right]$} \\
\hline & $\mathrm{Na}^{+}$ & $\mathbf{K}^{+}$ & $\mathrm{Cl}^{-}$ & $\mathbf{M g}^{2+}$ & $\mathrm{Ca}^{2+}$ \\
\hline Control (A) & $135.02 \pm 0.06^{b c}$ & $4.88 \pm 0.42^{\mathrm{a}}$ & $91.51 \pm 1.67^{\mathrm{ab}}$ & $0.68 \pm 0.04^{b}$ & $0.34 \pm 0.04^{s}$ \\
\hline ALC (B) & $88.27 \pm 0.79^{\mathrm{a}}$ & $6.37 \pm 0.41^{c}$ & $89.81 \pm 1.27^{\mathrm{a}}$ & $0.33 \pm 0.03^{\mathrm{a}}$ & $0.35 \pm 0.07^{\mathrm{a}}$ \\
\hline$A L C+125 \mathrm{mg} \mathrm{A} \cdot \mathrm{V}(\mathrm{C})$ & $120.94 \pm 0.09^{\mathrm{ab}}$ & $5.88 \pm 0.20^{\mathrm{bc}}$ & $94.26 \pm 1.16^{a b}$ & $0.63 \pm 0.04^{b}$ & $0.34 \pm 0.04^{a}$ \\
\hline$A L C+250 \mathrm{mg} \mathrm{A.V}(\mathrm{D})$ & $97.45 \pm 0.09^{\mathrm{a}}$ & $4.73 \pm 0.45^{b}$ & $93.56 \pm 0.67^{\mathrm{ab}}$ & $0.57 \pm 0.01^{b}$ & $0.34 \pm 0.03^{\mathrm{a}}$ \\
\hline $125 \mathrm{mg} A . V(E)$ & $167.61 \pm 0.26^{\mathrm{bb}}$ & $5.87 \pm 0.41^{\mathrm{bb}}$ & $90.93 \pm 2.14^{\mathrm{bb}}$ & $0.63 \pm 0.04^{b}$ & $0.34 \pm 0.03^{b}$ \\
\hline $250 \mathrm{mg} \mathrm{A.V}(\mathrm{F})$ & $175.10 \pm 0.34^{d}$ & $5.31 \pm 0.28^{b}$ & $95.40 \pm 1.67^{b}$ & $0.64 \pm 0.03^{b}$ & $0.35 \pm 0.05^{\mathrm{a}}$ \\
\hline
\end{tabular}

These data are expressed as the mean $\pm \operatorname{SEM}(n=5)$. Values with different superscript letters along the column for each parameter differ $s$ ignificantly at $\mathrm{P}<0.05 ; \mathrm{ALC}+125 \mathrm{mg} \mathrm{A}$. V—alcohol $+125 \mathrm{mg} \cdot \mathrm{kg}^{-1}$ body weight Aloe vera; ALC $+250 \mathrm{mg} \mathrm{A}$. V—alcohol $+250 \mathrm{mg} \cdot \mathrm{kg}^{-1}$ body weight

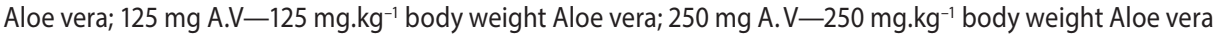

and LDH were reduced to a comparable level to the normal control $(\mathrm{P}<0.05)$. No significant effect was observed in the specific activities of GST following the treatment with $125 \mathrm{mg}$ and $250 \mathrm{mg} \cdot \mathrm{kg}^{-1}$ body weight Aloe vera gel extract when compared to group A.

The effects of Aloe vera gel extract on serum: bilirubin, urea, uric acid, albumin and creatinine levels in alcohol intoxicated rat are depicted in Table 5. The administration of alcohol resulted in a significant increase in serum: bilirubin, uric acid, urea and creatinine concentrations, while a significant $(\mathrm{P}<0.05)$ decrease was observed in the albumin level when compared to group A. Co-treatment with Aloe vera gel extract (groups $C$ and D) caused a marked decrease when compared to group $B$ with the exception of group $\mathrm{C}$ albumin concentration. More so, the administra- tion of Aloe vera gel extract only (groups E and F) showed no significant difference in the concentration of creatinine when compared with group respectively.

The effects of Aloe vera gel extract on serum electrolytes levels of alcohol intoxicated rats are depicted in $\mathrm{Ta}-$ ble 6. Alcohol ingestion lowered the levels of serum $\mathrm{Na}^{+}$ and $\mathrm{Mg}^{2+}$, while a marked increase was observed in $\mathrm{K}^{+}$level in rats when compared to the control group $(\mathrm{P}<0.05)$. No significant difference was observed in serum $\mathrm{Ca}^{2+}$ and $\mathrm{Cl}^{-}$ levels. However, co-treatment with Aloe vera gel extract (125 and $250 \mathrm{mg} \cdot \mathrm{kg}^{-1}$ body weight) resulted in a marked increase in the serum $\mathrm{Mg}^{2+}$ and reduced the serum $\mathrm{K}^{+}$levels as compared to the alcohol treated group (B). The administration of $125 \mathrm{mg}$ and $250 \mathrm{mg} \cdot \mathrm{kg}^{-1}$ body weight Aloe vera extract only (groups $\mathrm{E}$ and $\mathrm{F}$ ), showed no significant 
difference in the concentrations of magnesium and calcium as compared to control group (A) respectively.

\section{DISCUSSION}

The liver and kidney are two important organs which play important roles in physiological processes and excessive alcohol consumption damages these organs, and may lead to alterations in their metabolic activities [12, 23]. Alanine aminotransferase (ALT), aspartate aminotransferase (AST), alkaline phosphatase (ALP), gamma glutamyl transferase (GGT) and lactate dehydrogenase (LDH) are the most sensitive biomarkers directly implicated in the extent of tissue damage and toxicity [4, 24, 29, 32]. These enzymes are considered as indicators of liver and kidney malfunction and damage [16]. The leakages of these marker enzymes out from the necrotic hepatocytes into the blood stream in abnormal amounts are diagnostic of liver and kidney dysfunctions [4, 9, 20, 24]. More so, glutathione-S-transferase (GST) is an important enzyme that plays a crucial role in the detoxification and metabolism of many foreign and endobiotic compounds $[17,19]$.

This study demonstrated that, co-treatment with different concentrations (125 mg and $250 \mathrm{mg} \cdot \mathrm{kg}^{-1}$ body weight) of Aloe vera gel extract significantly $(\mathrm{P}<0.05)$ restored the elevated specific activities of serum: AST, ALT, ALP, LDH, GGT and GST, when compared to group administered alcohol only (group B). These restorative effects of Aloe vera on the specific activities of these tissue damage marker enzymes might be due to its hepato-renoprotective activities as reported by $\mathrm{Cu}$ i et al. [8], $\mathrm{H}$ u s s a in et al. [16], $\mathrm{R}$ aks ha et al. [25] and S a ka et al. [28] which enable it to protect the liver and kidney against the deleterious effects of alcohol.

The significant decrease $(\mathrm{P}<0.05)$ in the specific activities of ALT and ALP in the kidney observed in this study further supports reports that ethanol causes the leakage of the biomarker enzymes into the serum $[4,17]$. Whereas, the elevated specific activities observed in the stomach of these biomarker enzymes might be due to the amount and duration of ethanol exposure which might influence the results as observed. The significant increase in the specific activities of the tissues (liver, kidney and stomach) GST might be the response of the enzyme to detoxify the toxic metabolites produced by alcohol [17]. The reduction observed in the specific activities of kidney and stomach
GST as a result of Aloe vera gel co-administration, may be attributed to the anti-toxicity properties of bioactive substances in the extract which enable it to restore the tissues from the debilitating effects of alcohol.

Serum albumin is produced in the liver and it is the most abundant blood plasma protein which plays a key role in the transport of hormones, anaesthetics, endogenous ligands and free fatty acid [10], whereas, bilirubin is a breakdown product of haeme [31]. Both are recommended for the assessment of hepatobiliary injury in preclinical studies and are useful clinical clues to the severity of hepatic necrosis [31]. Creatinine is a waste product of creatine phosphate by muscle metabolism, while urea and uric acid which are excreted in urine are the breakdown products of protein and purine metabolism respectively [16]. The observed concentrations of serum bilirubin, creatinine, urea, uric acid as well as albumin in this study are consistent with previous reports $[3,31]$ that alcohol ingestion causes the accumulation of bilirubin, creatinine, urea, uric acid and decrease in albumin concentration in the serum. Co-treatment with $125 \mathrm{mg}$ and $250 \mathrm{mg} \cdot \mathrm{kg}^{-1}$ body weight Aloe vera gel however, significantly increased the serum albumin concentration and decreased the serum levels of bilirubin, creatinine, urea and uric acid to a comparable level to that of the controls. Modulations of serum bilirubin and albumin by Aloe vera gel extract might be due to the enhancement of the activity of the microsomal enzyme UDP-glucuronyl transferase (UDPGT), which is responsible for the conjugation reaction and thus controls hyperbilirubinaemia [31].

Hypomagnesaemia is the most common electrolyte disturbance in alcoholics and the mechanisms for development of hypomagnesemia in alcoholism include: increased transfer of magnesium from extracellular to intracellular fluid $[1,12]$. This is usually due to respiratory alkalosis and increased magnesium excretion which may occur in hypophosphatemia that causes reduced magnesium reabsorption at the loop of Henle and the distal tubules [1]. The serum sodium $\left(\mathrm{Na}^{+}\right)$level is determined by the balance of fluid in relation to the availability of sodium in the system [12]. Hyponatremia does not only constitute a biochemical abnormality but also has clinical consequences [12]. Normally the kidneys are a major route of potassium ion $\left(\mathrm{K}^{+}\right)$excretion and serve as an important site of potassium regulation [6]. Alcohol consumption historically has been found to reduce the amount of potassium excreted by the 
kidneys [6]. The levels of potassium, like those of sodium, also can affect the way the kidneys handle fluid elimination or retention and its depletion has been proposed to exacerbate hyponatremia [11]. Chloride as a major anion is important in the maintenance of the cation/anion balance between the intracellular and extracellular fluids and is also essential to the control of proper hydration, osmotic pressure and acid/base equilibrium [7]. The observed significant $(\mathrm{P}<0.05)$ hypomagnesemia, hyponatremia and hyperkalemia ensued after alcohol administration in this study, were completely reversed back to normal following co-treatment with Aloe vera gel. The modulatory effect of this extract on the serum $\mathrm{Na}^{+}$level is consistent with the study of $\mathrm{S}$ a k a et al. [28] where Aloe vera gel extract elevated the serum $\mathrm{Na}^{+}$level in rats. Although, to the best of our knowledge, little or no report is known of the ameliorative effect of Aloe vera gel on alcohol induced hypomagnesemia. Raksha et al. [25] recognized the presence of $\mathrm{Mg}^{2+}$ in the Aloe vera gel extract as part of its phytochemical screening and this might be responsible for the reversal of hypomagnesemia. Moreover, the general restorative effects of the extract on alcohol induced electrolytes imbalances could be attributed to the bioactive substances present in the polysaccharides of the extract. These bioactive components are said to be responsible for Aloe vera gel therapeutic effects and could account for its modulatory ability to ameliorate electrolytes disturbances $[4,7]$.

\section{CONCLUSIONS}

This study demonstrated that Aloe vera gel (250 mg.kg-1 body weight) could alleviate alcohol induced liver and kidney injury by decreasing the level of bilirubin, uric acid and urea and increasing the albumin level as well as lower the elevated marker enzymes and modulate the electrolytes disturbances. It is therefore suggested that Aloe vera gel could be used as part of decoction in the management of alcohol induced liver and kidney dysfunction.

\section{ACKNOWLEDGEMENTS}

The authors would like to express their appreciation to Mr Mosebolatan Joshua for giving his support during the period of the experiments. We also wish to state that the re- search did not receive any form of funding and it was carried out as a means of encouraging the undergraduate and postgraduate students in the area of biomedical research.

\section{REFERENCES}

1. Adewale, A., Ifudu, O., 2014: Kidney injury, fluid, electrolyte and acid-base abnormalities in alcoholics. Nig. Med. J., 55, 2, 93-98. DOI: 10.4103/0300-1652.129631.

2. Akinloye, D. I., Ugbaja, R. N., Dosumu, O. A., 2019: Appraisal of the antioxidative potential of Aloe barbadensis M. on alcohol induced oxidative stress. Folia Veterinaria, 63, 3, 34-46. DOI: 10.2478/fv-2019-0025.

3. Aldalou, A. R., Abdel-Aziz, I., Shahwan, O., 2013: Effects of chromium on some haemato-biochemical parameters in domestic rabbits. Int. J. Biol. Pharm. Res., 4, 847-854.

4. Al-Shinnawy, M. S., Hassan, A. R., Ismail, D. A., Shahin, M. A., 2014: The potential protective and therapeutic effects of Aloe vera juice on malathion induced hepatotoxicity in rabbits. Egypt. J. Hosp. Med., 55, 146-158. DOI: 10.12816/ 0004500 .

5. Ashafa, A. O. T., Sunmonu, T. O., Abass, A. A., Ogbe, A. A., 2011: Laxative potential of the ethanolic leaf extract of Aloe vera (L.) Burm. f. in Wistar rats with loperamide-induced constipation. J. Nat. Pharm., 2, 3, 158-162. DOI: 10.4103/ 2229-5119.86268.

6. Cecchin, E., De Marchi, S., 1996: Alcohol misuse and renal damage. Addict. Biol., 1, 1, 7-17. DOI: 10.1080/1355621961 000124656 .

7. Chandini, P., 2017: Serum electrolytes levels in patients with alcohol dependence syndrome. J. Contemp. Med. Sci., 4, 5, 992-997.

8. Cui, Y., Wang, H., Li, W., Yao, W., Qian, H., 2014: Hepatoprotective potential of Aloe vera polysaccharides against chronic alcohol induced hepatotoxicity in mice. J. Sc. Food Agric., 94, 1764-1771. DOI: 10.1002/jsfa.6489.

9. Das, S. K., Vasudevan, D. M., 2008: Alcohol induced effects on kidney. Indian J. Clin. Biochem., 23, 1, 4-9. DOI: 10.1007/ s12291-008-0003-9.

10. Devi, V.S., Chidi, O. O., Coleman, D., 2009: Dominant effect of ethanol in thermal destabilization of bovine serum albumin in the presence of sucrose. Spectroscopy, 23, 5-6, 263-270. DOI: 10.3233/SPE-2009-0400.

11. Epstein, M., 1992: Alcohol and the kidney. In Lieber, C. S. (Ed.): Medical and Nutritional Complications of Alcoholism: 
Mechanisms and Management. Plenum Medical Book Company, New York, 495-513. DOI: 10.1007/978-1-4615-33207_16.

12. Epstein, M., 1997: Alcohol's impact on kidney function. Alcohol, Health Res. World, 21, 1, 84-93.

13. Gopinathan, S., Naveenraj, D., 2013: Gastroprotective and anti-ulcer activity of Aloe vera juice, papaya fruit juice and Aloe vera and papaya fruit combined juice in ethanol induced ulcerated rats. Intl. J. Drug Dev. Res., 5, 4, 300-311.

14. Habig, W., Pabst, M. J., Jakoby, W. B., 1974: The first enzymatic step in mercapturic acid formation. Glutathione-Stransferase. J. Biol. Chem., 249, 7130-7139.

15. Heier, C., Hao, X., Robert, Z., 2016: Nonoxidative ethanol metabolism in humans-from biomarkers to bioactive lipids. IUBMB, 68, 12, 916-923. DOI: 10.1002/iub.1569.

16. Hussain, N., Chaudhary, M. N., Anjum, A. A., Abbas, N., Khan, M. N., Nadeem, S. M., 2016: Investigating the ameliorative potential of Aloe barbadensis aqueous fraction on oxidative stress markers and biochemical parameters in cadmium intoxicated rats. Pol. J. Environ. Stud., 25, 6, 2423-2433. DOI: $10.15244 /$ pjoes/64239.

17. Ighodaro, O. M., Omole, J. O., 2012: Ethanol-induced hepatotoxicity in male Wistar rats: Effects of aqueous leaf extract of Ocimum gratissimum. J. Med. Med. Sci., 3, 8, 499-505.

18. Imaga, N. O. A., Ebuechi, O. A. T., Edom, J. J., Obomniru, G. E., Oyadina, O. O., 2016: Evaluation of the therapeutic effects of Aloe vera gel on alloxan-induced diabetic rats. Nig. Q. J. Hosp. Med., 26, 2, 377-386.

19. Ji, X., Zhang, P., Armstrong, R. N., Gilliland, G. L., 1992: The three-dimensional structure of a glutathione $\mathrm{S}$-transferase from the mu gene class. Structural analysis of the binary complex of isoenzyme 33 and glutathione at 22 ANG. Resolution. Biochem., 31, 42, 10169-10184. DOI: 10.1021/bi00157a004.

20. Lee, H. I., McGregor, R. A., Choi, M. S., Seo, K. I., Jung, U. J., Yeo, J., et al., 2013: Low doses of curcumin protect alcohol induced liver damage by modulation of the alcohol metabolic pathway, CYP2E1 and AMPK. Life Sci., 93, 693699. DOI: 10.1016/j.lfs.2013.09.014.

21. Manvitha, K., Bidya, B., 2014: Aloe vera: a wonder plant, its history, cultivation and medicinal uses. J. Pharmacogn. Phytochem., 2, 5, 85-88.

22. Ni, Y., Yates, K. M., Tizard, I. R., 2004: Aloe polysaccharides. In Reynolds, T., (Ed.): Aloes the Genus Aloe. CRC Press, Boca Raton, USA, 75-87 pp.

23. Niemela, O., 2007: Biomarkers in alcoholism. Clin. Chim. Acta, 377, 39-49. DOI: 10.1016/j.cca.2006.08.035.
24. Padmanabhan, P., Jangle, S. N., 2014: Hepatoprotective activity of herbal preparation (HP-4) against D-Galactosamine induced hepatotoxicity in mice. Intl. J. Pharm. Sci. Drug Res., 6, 1, 31-37. DOI: 10.3126/ijasbt.v2i1.9346.

25. Raksha, B., Pooja, S., Babu, S., 2014: Bioactive compounds and medicinal properties of Aloe vera L.: An update. J. Plant Sci., 2, 3, 102-107. DOI: 10.11648/j.jps.20140203.11.

26. Reddy, U., Reddy, C. H., Reddy, J., 2011: Aloevera - a wound healer. AJOHAS, 1, 91-92.

27. Rukkumani, R., Aruna, K., Suresh, V. P., Menon, V. P., 2004: Influence of ferulic acid on circulatory prooxidant. J. Physiol. Pharmacol., 55, 3, 551-561.

28. Saka, W. A., Akhigbe, R. E., Ishola, O. S., Ashamu, E. A., Olayemi, O. T., Adeleke, G. E., 2012: Hepatotherapeutic effect of Aloe vera in alcohol induced hepatic damage. J. Biol. Sci., 14, 14, 742-746. DOI: 10.3923/pjbs.2011.742.746.

29. Saritha, V., Anikulamar, K. R., 2010: Toxicological evaluation of methanol extract of Aloe vera in rats. IJPBR, 1, 5, 142-149.

30. Scott, R. B., Reddy, K. S., Husain, K., Schlorff, E. C., Rybak, L. P., Somani, S. M., 2000: Dose response of ethanol on antioxidant defence system of liver, lung, and kidney in rat. Pathophysiol., 7, 1, 25-32. DOI: 10.1016/S0928-4680(99)00034-6.

31. Senthilkumar, T, Asha, S. K., 2015: Selective and sensitive sensing of free bilirubin in human serum using water-soluble Polyfluorene as fluorescent probe. Macromol., 48, 11, 34493461. DOI: 10. 1021/acs.macromol.5b00043.

32. Shanmugam, K. R., Ramakrishna, C. H., Mallikarjunaa, K., Sathyavelu, R. K., 2010: Protective effect of ginger against alcohol induced renal damage and antioxidant enzymes in male albino rats. Indian J. Exp. Biol., 48, 143-149.

33. Shield, K. D., Charles, P., Jürgen, R., 2014: Chronic diseases and conditions related to alcohol use. Alcohol Res.: Current Reviews, 35, 2, 155-173.

34. Soni, H., Sharma, S., Singhai, A. K., 2011: Qualitative and quantitative profile of aloin isolated from Aloe vera. Int. Res. J. Pharm., 2, 9, 121-122.

35. Talmadge, J., Chavez, J., Jacobs, L., Munger, C., Chinnah, T., Chow, J. T., 2004: Fractionation of Aloe vera L. inner gel, purification and molecular profiling of activity. Int. J. Immunopharmacol., 4, 1757-1773. DOI: 10.1016/j.intimp. 2004.07.013.

Received August 4, 2020

Accepted December 13, 2020 